\title{
Talent Management: The Good, the Bad, and the Possible
}

\author{
Mollie Painter-Morland, ${ }^{1}$ Susan Kirk, ${ }^{1}$ Ghislain Deslandes ${ }^{2}$ \\ and Carole Tansley ${ }^{1}$ \\ ${ }^{1}$ Nottingham Business School, Nottingham, UK \\ ${ }^{2}$ ESCP Europe, Paris, France
}

\begin{abstract}
In this essay we offer a critical investigation of talent management practices (TMP), which is an increasingly influential concept in contemporary organisations. We try to show how these organisational practices could have both a negative and a positive ethical impact on those identified as 'talent' within organisations. A critical analysis of how talent is defined, and how this impacts on individuals' capacities for ethical reflection, allows us to highlight the ethical ambiguity inherent in talent management (TM). We then highlight examples of some 'bad' consequences of $T M$, and explore some 'good' counter-examples. To highlight what may be 'possible' in talent management, we propose a more constructive relationship between talent management and ethics based on two dimensions: (1) the acceptance of ambiguity and personal struggle and (2) the development of more qualitative approaches to performance that could enable a better understanding of and sensitivity towards the broader context within which organisations function.
\end{abstract}

Keywords: talent management discourse; ethical reflection; ethical freedom; self-reflection; Foucault

\section{Introduction}

Talent management (TM) is a corporate buzzword that has become a priority of boards of directors, HR managers and recruitment agencies alike. We believe that amidst all of the noise and activity some critical questioning regarding the ethical implications of all the buzz around 'talent' is much needed. Management scholars have suggested that a closer look at talent management practices, wherein the need for an ethical analysis of these practices lies latent. For instance, in this very journal, Van den Brink et al. (2013) called for a reflexive practice-based assessment of talent management. Dries (2013: 282) suggested that discourse and narrative are important future areas of talent management research. Holden and Vaiman (2013: 142) also call for 'studies into contrasting ways of transferring talent management concepts and practices'. The ethical dimension of the TM discourse however remains largely unexplored. The existence of this 'elephant in the room' is not surprising, given that the term

[Correction added on 21 February 2018 after first online publication: The order of the second and fourth authors has been updated in this current version.]

Correspondence: Ghislain Deslandes, ESCP Europe, 79 Avenue de la République, 75011 - Paris, France, Tel: +33149232063; Fax: +33149232069. E-mail gdeslandes@hotmail.com talent management has been described as a euphemism for the 'use' of elite human resources, thus failing to conform to the basic ethical principle of not using people as a means to an end (Greenwood, 2002: 261). An exception to the silence around the ethics of TM is in the work of Swailes (2013), who identified ways in which the establishment of managerial elites in organisational initiatives, such as talent management, clearly raises concerns in relation to class, gender, power and ethics.

In this essay, we therefore take up the challenge to offer new insights on talent management as 'an important management issue' (Jardat, 2015), taking an explicitly ethical perspective. Ethical questioning involves considering whether certain norms and values may be violated in and through TM practices, and whether someone may be harmed in the process (Painter-Morland and ten Bos, 2011). Our ethical analysis of TM practices will therefore focus on the possibility that it may undermine individuals' capacity to consider norms and values, and the effects their actions may have on others. To avoid this, supporting talent's critical self-reflection and ethical judgment is crucial. This involves the practice of considering one's perceptions and actions from a normative perspective, that is, taking norms and values and the interests of others and the broader society into account. 
To enable us to perform this ethical analysis, talent management discourse and practice must be studied to reveal its effects on subject-formation over time. We will investigate how TM may influence the subject's struggles with others, and how this may shape institutional dynamics that may negatively affect others or violate norms and values. For this we draw on Michel Foucault to inform our analyses of the conditions for ethical freedom. We will focus on Foucault's later work, in which he discussed various practices of self-writing as part of the ethical agency of individuals. We end our analysis with some proposals on how to reform such practices in order to protect and foster talent's self-reflection and ethical judgment. To do so, we again use the insights we gained from our Foucauldian analysis to highlight the ways in which talent management could support ethics in organisations. In order to frame this ethical analysis of $\mathrm{TM}$, however, we need to explain the discursive force of the talent management discourse, to which we now turn.

\section{Talent management as a discourse framing managerial practice}

Though 'talent management' may have reached the status of buzz-word only relatively recently, its genealogy stretches very far back. The concept of 'talent' was first used in the Bible to denote a unit for the measurement of silver (Tansley, 2011), that is, the word always designated something precious or rare. Since then, the concept has been used to signal skills or gifts that individuals are deemed to have in all spheres of life, including the workplace. By the 1990s, employees with 'talent' were held to be so scarce, that a 'war for talent' was declared (Michaels et al., 2001). Since then debates have raged about the meaning of the term and the exclusivity of its interpretation within the workplace, leading commentators to observe that notions of talent are context-bound, gendered (Gallardo-Gallardo et al., 2013) and a 'problematic, not a value-free activity' (Iles, 2013:302). Some have suggested that talent management is merely 'a re-labelling of HRM' (Iles, 2013: 302), others postulate that it is a 'faster and/or better' approach to HRM, or, in its more exclusive form, simply a more cost-effective way of managing people by investing in those deemed to have more potential (Gallardo-Gallardo et al., 2013: 295). In short, the debate continues as to whether or not TM is a substitute for, or a complement to, HRM.

The debate surrounding the meaning of talent management also hinges on the extent to which it is seen as an inclusive or exclusive approach (Downs and Swailes, 2013). Michaels, Handfield-Jones and Axelrod (2001) define 'talent' as a 'special aptitude' possessed by a minority of individuals who can make the greatest difference to organisational performance, either through their immediate contribution or in the longer term by demonstrating the highest levels of potential' (Tansley, 2011: 267). The underlying talent philosophies of those in charge influence the approach to talent management adopted (Meyers and van Woerkom, 2014), but a common stance on this phenomenon is that is constitutes an exclusive organisational approach involving the identification and management of a minority of highperforming individuals who are aligned to organisational goals (Björkman et al., 2013). According to Thunnissen et al. (2013), talent management is a top-down approach derived from what Swailes (2016: 347) calls 'corporate thinking'. In other words, approaches to talent management are derived from senior stakeholders' and key organisational decision makers' views and are cascaded down the management hierarchy. The design and implementation of $\mathrm{TM}$ practices to enact these philosophies are the domain of HR professionals (Kim et al., 2014). Whatever the underpinning ethos, talent management involves 'an integrated set of processes, programs, and cultural norms in an organisation designed and implemented to attract, develop, deploy, and retain talent to achieve strategic objectives and meet future business needs' (Silzer and Dowel, 2010: 18).

Talent management can be usefully described as a socially constructed and organised system of meaning (Burr, 2003) comprising a set of connected concepts, terms, statements and expressions which constitute a way of thinking and communicating about this concept which provides a guiding trajectory for the ways in which people feel, respond to and enact it (Watson, 1995). We therefore take talent management as a set of material and languagebased practices "where individual language users draw on "discursive resources", i.e. expressions, words, images, practices and symbolic behaviour "to construct persuasive accounts to make sense of, achieve and legitimise their life and work projects"' (Watson, 1995 in Tansley and Tietze, 2013: 5). Talent management practices underscore the close connection between thinking and doing, that is, discourses influencing actors' thinking and communication which, in turn, frames cognition and action (Van Dijk, 2014). Talent management discourse in an organisation can vary according to the size and complexity of the organisation, with perhaps different definitions at the individual and group level and different biases across languages. Such definitions can also alter over time in response to changes in the environment (e.g., labour supply), thus meanings are context-driven and cannot perforce be universal (Thunnissen et al., 2013).

\section{Ethical risks within talent management}

Talent management is fraught with ethical risks and dilemmas. These implications emerge from how talent is 
defined, as well as how talent management practices influence individuals' capacity for ethical reflection. In her analysis of which ethical principles may promote a positive relationship between ethics and HRM, Greenwood (2002: 275) highlights the importance of the minimal conditions of treating people with respect, and not interfering with the freedom of the individual. In what follows, we contend that in both these respects, talent management can present serious ethical risks.

Defining talent is certain ways can either restrict or increase the freedom of individuals to act in more or less ethical ways (Swailes et al., 2014), precisely because it potentially structures the relationship between people. Conceptualisations of talent management are, arguably often, 'sustained by narratives of scarcity and metaphors of war in relation to high-level skills' (Downs and Swailes, 2013: 268). The mere designation of some as scarce 'talent', implies that most others are 'untalented', or at least inferior in some ways. Hierarchical classification of staff as 'emerging stars', 'rising stars' or 'corporate stars' come with benefits and penalties that have a material impact on the lives of individuals within the specific organisation and in their further careers. For those formally identified as organisational talent, accepting a place on a talent management programme will mean having to accept high levels of discursive pressure to identify with the espoused organisational values and identity. However, for those not labelled as 'talent' there may be feelings of demotivation, a loss of a sense esteem and perceptions of inequity. This, in turn, can lead to high turnover among 'moderately high performers' who feel they have been undervalued (Collings, 2014: 313). The ethical challenge that is posed, is clearly the issue of how equal respect and consideration for all organisational members can be maintained.

In addition, the way in which talent management operates shape individuals' capacities for ethical reflection. TM discourses are utilitarian in tone presenting people as a means to an end, rather than as human beings worthy of respect regardless of their outputs. The discursive mechanisms that support organisational life create 'pervasive logic' (Townley, 2008) that guides both organisational and individual activities. In turn, there is a danger that management will assume that talent will unquestioningly conform to its underlying instrumental 'logic' (Björkman et al., 2013).

One of the central problems with talent management discourse relates to the fact that its influence can isolate the employee from others within the organisation, conferring on these individuals an identity which carries contradictory connotations of elitism and, at the same time, subjugation to the dominant narrative. It can also perpetuate a form of dis-identification (Kunda, 1992; Sturdy, 1998; Whittle, 2005) or even self-alienation (Costas and Fleming, 2009: 354) where individuals reject the identity they perceive to be 'alien and foreign'.
On the other hand, individuals who wholly embrace such discourses and seek to reinvent themselves to align with the organisational script may engage in identity-work that precludes the space for self-reflection and ethical judgment (Alvesson and Willmott, 2002). In terms of talent management discourse, then, the question is to what extent do such a bundle of discursive practices function as 'normalising techniques' that makes it inevitable that those who have accepted an identity of 'talent' will follow the 'script' of what the organisation wants him/her to be in order to meet organisational ends. If so, we suggest that the self-fulfilling prophecy written into some such organisational narratives leads to a self-renunciation that makes moral responsiveness impossible. Randall and Munro (2010: 1490) for instance point out that many organisational discourses perpetuate this kind of 'disciplinary normalization', or 'normation' of the individual body. They argue that within the context of mental health work, these kinds of normalising processes lead only to a culture of dependence and blame.

Talent management discourses have been criticised for adhering to the requirements of a 'decision-science' where investments are made in the areas that generate the biggest profits (Meyers and van Woerkom, 2014). However, despite links between drawn between TM, organisational performance and profits, empirical evidence to support such assertions is lacking (Gallardo-Gallardo et al., 2013). Nonetheless, such discourses seem prone to the kind of goal-setting, goal measurement and identity construction that tends to precipitate conformation to dominant discourses, rather than critical reflection on them.

This is not to say, however, that there is only one discourse or that discourse alone dictates outcomes, as organisations are polyphonic, constituted of multiple voices (Cunliffe and Coupland, 2011). We recognise that, as Alvesson and Kärreman (2011: 1136) argue, for a discourse to have 'a clear constitutive effect', then it has to be 'anchored in, and supported by, social norms and institutions'. So, where talent management practices are strongly aligned to a dominant discourse that encourages self-interest and stifles ethical debate, then this can result in negative consequences both for the organisation and the individual. As will be explored in more detail later, Enron could be seen as an example of an organisation where various dimensions of the organisation were designed to support the negative ethical implications of the talent management discourse. Both in terms of how talent was defined, and how the HR system supported unethical competition between employees, talent management formed part of a discursive and material environment.

However, that is not to say that discourses, practices and material conditions cannot conspire towards more 
ethical reflection. In what follows, we explore both potential negative effects of TM on ethics in organisations, as well as some counter-examples of instances in which organisations succeeded in using talent management to strengthen a concern for ethics and sustainability within their organisations.

\section{The 'bad': Ethical risks within talent management}

An unquestioning response to organisational discourses can perpetuate an uncritical acceptance of 'the way we do things around here' and certainly it would seem that the formal identification of 'talent' encourages such an acceptance (Björkman et al. 2013). Some contend that the identity of 'talent' proffers a 'story type or template' (Thornborrow and Brown, 2009: 370) which confers meaning and adds to the 'narrative repertoires' (Ibarra and Barbulescu, 2010: 135) upon which these individuals can actively draw to develop and craft their own selfnarrative. Such narrative repertoires may also be employed to navigate the coexistence of coherence and ambiguity during career transitions (Hoyer and Steyart, 2015), and/or act as sense-making and legitimation strategy leadership decisions (Maclean et al., 2011). For many, being designated as 'talent' offers some individuals a resolution to the identity struggles they may face in navigating the complexities of the modern workplace (Maclean et al., 2011). Sveningsson and Alvesson (2003: 1164) suggest that, within organisation studies, the focus has shifted from an interest in who individuals and organisations are, to who they are becoming. If being designated as 'talent' makes fluidity in the interaction between individuals and others within different organisational settings impossible, it can also become a straightjacket that restricts their freedom. This can occur if talent management discourse is solely directed at protecting the organisation's side of the employment bargain.

In fact, it is in this context that certain talent management practices have been blamed for incentivising unethical behaviour (Swailes, 2013). For instance, the well-documented case of Enron and the talent practices that encouraged and rewarded narcissistic behaviour (Swailes, 2016). Enron recruited candidates whom they considered suitably "bold, hungry and creative." Shorttermism and the ruthless pursuit of profits characterised the reward structure at Enron (Fusaro and Miller, 2003: 52). The values of ruthless competition and greed were also integrated into the 'rank-and-yank' performance management system, which created brutal competition and self-interested behaviour (Spector, 2003). This performance management system resulted in the bottom $10-15 \%$ of performers being fired every year. The talent management approach was predicated on a culture of 'basic greed', where individuals were well paid and ultimately stopped asking questions about the unethical practices within the organisation (Beenen and Pinto, 2009).

The discourse, however, is not always so simple. Van den Brink et al. (2013) stress the paradoxes inherent in some talent management discourses: seeking control but needing to relinquish it for talent to flourish, especially in the case of academic talent that insist on academic freedom. Some talent practices are designed to serve equality and fairness in assessment, but instead entrench biases against minorities who are not represented in forums that determine what is considered 'excellent'. It is in these ways, that talent management can serve to institutionalise unethical practices.

The way in which TM can be an undermining force in terms of ethics, is also illustrated in the case of Amazon, where 'amabots' and 'bar raisers' are encouraged to compete and challenge one another through aggressive talent management practices upheld in so-called 'articles of faith' (Kantor and Streitfeld, 2015), expressions of the dominant, organisational discourse. These practices include being encouraged to work excessively long hours and to openly criticise one another. They are supported by an on-line feedback tool, a forced distribution system enabling performances to be compared and those deemed to be lacking are managed out. Financial incentives are used to motivate behaviour. A similar system is operated in Sports Direct, where 'workhouse conditions' are described as 'brutal, humiliating and even lifethreatening' (Calvard and Sang, 2017: 2257).

Paradoxically, even when organisations commit themselves to managing their organisations in an ethical way, they could still create further ethical risks. There have recently been attempts to signal the importance of certain ethical behaviours and value commitments in and through talent management mechanisms (Swailes, 2013). Formalised ethical training for talent will also not have the desired effect if it leads to routinised responses and blunts individual moral responsiveness. We suggest that referring to deontological and utilitarian principles will not suffice in establishing a proper relationship between talent management and ethics (see Jack et al., 2012: 2). Neither is a focus on the micro-dynamics of treating individuals fairly helpful in addressing the systemic influences of talent management on the organisation and on society.

The various iterations of 'self-control' so clearly central to talent management can shape the identity of individuals in ways that forecloses the kind of honest self-reflection that makes ethical judgment possible within organisations. For instance, Alvesson and Kärreman (2007) show how HRM initiatives (such as talent management) engender 'identity-alignment' by connecting organisational identity 
and individual identity-regulation through a combination of aspirational controls and material forms of power. They specifically highlight management's careful surveillance of any signs of negativity or any instance of people telling non-affirming stories. Grey (1994) also observed the techniques of surveillance that are inevitably part of contemporary workplaces and the way in which this institutionalises self-management. Others, like Glee and Roger (2004: 10) highlight the 'free voluntary submission' that is involved in subjects' engagement with their institutional environment. This has led authors to question whether talent management can indeed be prevented from becoming oppressive (Sewell et al., 2011). In what follows, we analyse instances within which talent management did indeed seem to have positive effects of ethics within organisations.

\section{The 'good'... exploring the ethical potential of TM:}

It has to be acknowledged that TM can in some cases also be a force for good. There have recently been attempts to signal the importance of certain ethical behaviours and value commitments in and through talent management mechanisms (Swailes, 2013). In response, some have suggested proactively integrating ethics into talent management processes. Tymon et al. (2010) argue that adopting a socially responsible approach to talent management practices, such as performance management and rewards, will increase intrinsic satisfaction and, in turn, commitment and retention. Others stress the need for organisational justice in recruiting, selecting and rewarding talent (Gelens et al., 2013).

An important theme to be found in the talent management literature is the way in which it is discursively utilised in creating the self-disciplined subject. Though the idea of self-disciplined subject is often criticised by critical management scholars (Alvesson and Kärreman, 2007), others view it as a more positive force. In their study of positive work identity, Dutton et al. (2010) describe different ways in which individuals attempt to positively evaluate their own identities within organisations. Whereas virtue-based evaluations operate with a sense of how certain individual character traits lead to admirable behaviour, many of the other aspects of positive identity evaluation rely on the individual's interaction with the institution. For instance, from the perspective of adaptive identity development, individuals engage in identity work to align their identities with the organisation's written or unwritten expectations.

Similarly, from an evaluative perspective, identity construction depends on the individual's ability to maintain a sense of self-worth within a social context or as a member of work teams. From the perspective of 'social exchange theory', it can be anticipated that individuals who have been identified as high-potential feel that they should reciprocate the organisation's investment in them by working harder and being more committed to staying with the organisation (Gelens et al., 2013). The IBM Smarter Plant initiative with its emphasis on corporate citizenship, Unilever's alignment of stakeholder management with their strategy of sustainability and Federal Express's environmental approach to transportation are all built on notions of ethical behaviour (Banks et al., 2016) designed to encourage such identification.

These organisations' talent management practices have been designed to support these normative priorities. IBM's 6 months' service corps programme within emerging economies has been designed to shape top talent to become the organisation's future leaders. Though it was initially thought that programme would involve 200 individuals per year, 5,000 applications were received in the first year, and it soon grew to accommodate 500 individuals per year. It includes 3 months' pre-work to develop insight into the local conditions and challenges that the participants will be embedded in, cultural awareness, language-skills, etc. followed by a month-long immersion in a developing country context to work on core societal, educational and environmental challenges in partnership with local NGOs, SMEs or public bodies. This is followed by 2 months' post-service work and continual sharing of perspectives and information with partners in the emerging economy, but also the sharing of learning with their colleagues back at the office, as well as with family and friends (Gitsham, 2008). IBM supplements this programme with regular 'ValuesJam' sessions to 'debate and consider the fundamentals of the values' of the organisation (Stahl et al., 2012: 28).

Unilever adopted a similar approach as part of their emerging markets strategy where those identified as potential talent work together in residentials and field visits to explore issues facing the poorest people, such as water usage and the implications of population growth etc. (Gitsham et al., 2008). Such initiatives have resulted in them being named as an example of good talent management practice (Krishnan and Scullion, 2017). But what exactly is it in the positive examples that could provide the space for a commitment to values and ethical reflection on the consequences of corporate action? We believe that Foucault's philosophy provides some clues.

\section{Foucault's ethics as inspiration for TM that supports ethical reflection}

The 2001 publication of Foucault's lectures at the College de France under the title 'The Hermeneutics of the Subject' (translated into English in Foucault, 2005) and 
the collection of his lectures and papers in English in the volume Ethics. The essential works 1 (1994), allow us to investigate his conception of the subject as a moral agent, that is, as an actor capable of moral deliberation and action. According to Foucault, the 'rapport à soi' - the relationship to oneself - is what gives meaning to the concept of the subject. In his opinion, the 'rapport à soi' is a way of 'thinking about the relationship one should have with one's positions, functions, activities, and obligations' (Foucault, 1994: 116-117; Deslandes, 2012a). This capacity to reflect, and critically respond to the relationships within which one is embedded, is central to Foucault's understanding of ethical freedom. The moral subject is not one whose actions and thoughts are consistent with a universal code; it is someone who takes a stand in relation to the rule and, to do so, undertakes to keep alive a relationship with him/herself and to examine his/her own conduct with a critical eye.

Foucault undertakes to make a distinction between knowledge of self (a key concept in reflexive philosophy from Socrates to Descartes and Fichte) and the care of self, quintessentially an aesthetical and ethical concern. Through his study of Socratic, Cynic and Stoic philosophical practices, Foucault rediscovers other ways of addressing ethical questions as the care of self. In his analysis of these practices, Foucault for example shows how subtle changes in how the practice of confession was used over the ages has caused it to become a practice of self-renunciation, rather than an exercise in the care of the self. Over time, the emphasis shifted from self-care to self-knowledge. This kind of 'corruption' of well-intended practices emerge because we lose sight of the subtle shift away from ethical relationships with the self and with others, towards 'objective knowledge' of performance.

Foucault's explanation for this is that the history of Western thought has given a central role to the thinking subject as the first step in developing a theory of knowledge. In the process, an implicit priority of "knowing yourself" over "taking care of yourself" emerged. We would contend that this priority of "knowing yourself" over "taking care of yourself" is equally evident within talent management practices. In the negative examples of talent management, 'self-knowledge' would be focused largely on one's instrumental use to the organisation, rather than on 'care of the self', which allows one to develop reflective capacities, and ethical relationships with others. The implicit assumptions regarding 'rational' and goal-directed' behaviour, knowing one's talents and making efficient use of it, are reflected in many aspects within a talent management system. Developing the 'talented' self in perfect alignment with organisational scripts does not always constitute selfcare, nor does it allow any space for critical self-reflection. If the individual measures him/herself against some ideal-type construction that serve managerial interest, that type is never questioned, nor is the implications of these 'types' for maintaining moral responsiveness unpacked. This limits the opportunity for meaningful self-reflection, as well as for a critical engagement with organisational practices.

Foucault's genealogical analysis draws attention to the way in which certain practices facilitate self-formation, while others encourage self-renunciation. These practices are reiterated in many religious, judicial and social discourses, yet we often fail to reflect on their meaning. Foucault's avocation of self-care suggests that one should focus on one's ethical substance, disassembling the various social and historical threads that constitute one's self. This involves a process of recreating oneself by literally disentangling the various practices by which the self is formed, and reframing its boundaries.

As Deslandes (2012b) explained, any care-of-the-self ethics involves self-evaluation (Hadot, 2002) and selftransformation. Foucault describes the need for techniques of the self, procedures prescribed in ancient Greece to establish one's identity. One such technique is selfwriting, where an individual lucidly questions him/ herself about his/ her weaknesses and strengths in a form of parresia, namely, truth-telling. Self-writing gives the individual the opportunity to think about him/herself, as full of potential for action but also as vulnerable, full of frailty and powerlessness. In the context of talent management, it is easy to see how certain discourses about the identity and expected values and behaviours of talent dictate what is relevant in employees' self-evaluations, potentially leading to arrogance, blindness to one's own flaws or mistakes, or an unwillingness to give fair credit to others.

Townley (1993) points out that some appraisal schemes require agreed objectives and evaluations, whereas in others, the appraiser's role is clearly defined as 'judgemental'. Within the latter, targets and other KPIs are portrayed as 'objective' measures to ensure that the process is 'rational' and 'fair'. Yet in the process, the employee's ability to engage in 'care of the self', which is thoroughly embodied and contextual (Townley, 2002), may be lost. In the cases of Enron and Amazon that were discussed earlier, these dangers loom large.

Is there a way out of this problem? Foucault argues that we are inheritors of a social morality that seeks the rules for acceptable behaviour in our relations with others, yet we are not mere passive recipients of this inheritance (Foucault, 1994). Studying organisational practices over time allows us to problematise what happens to identity, both on personal and organisational level, and to push back against institutional forces. Foucault moves beyond a view of power as a repressive force. He redefined power relations by making a distinction between power relations as strategic games between liberties, and the states of domination that people ordinarily call 'power'. 
Between the two, between strategic games and states of domination, one also encounters technologies of government. 'Governmentality' implies a relationship of the self to itself, but goes beyond the self to define, organise and instrumentalise the strategies that individuals, in their freedom, use in dealing with each other. 'Subjectification' - a space of freedom paradoxically formed by oppositions and constant changes - is the outcome of governmentality, the product of a constant struggle with the ruling authorities (Jones, 2002; Ibarra-Colado et al., 2006; Crane et al., 2008). Here we can also mention the name of De Certeau (1990) who tried to go further than a discursive approach by showing that people, even the weakest ones, have the capacity to resist the strategic power of organisations (Hjorth, 2005). Talent management practices as an example of this strategic power can be diverted into irony and 'camouflages' for self-reinvention as tactical places and counter actions for emancipation and subversion. De Certeau's theory of the prosaic of the everyday (Dey and Teasdale, 2016) can help us to understand that despite the power of TMP, employees and managers are not only passive bodies but active ones, capable of using their time wisely in a way which is not dictated by the corporation's clock. Forces of alienation like negative talent management practices can be undermined by forces of liberation (Mboukou, 2015; Courpasson, 2017).

Foucault posits that genealogical analyses creates spaces for ethical freedom to operate. Some consideration of how words like 'talent', and the practices that emerge from it, influence the relationships of power in organisations, could open the possibility of struggle, which may allow space for ethical freedom. This may include, for instance, the use of dialectical irony (Sewell et al., 2011), or the opportunistic use of tactics, drawing on intimations born of an assessment of current conditions and constraints (Barratt, 2008). In his analysis of what the later Foucault offers organisation studies, Barratt (2008) points out that instead of viewing resistance as voicing disengaged, detached objections, Foucauldian resistance entails a very practical, tactical engagement with the political and social dynamics within organisational spaces. In fact, the image of the critic that Foucault would endorse is that of the tactician who pursues 'the opportunistic practice of struggling to manipulate events into opportunities' (Barratt, 2008: 533). Foucault's view of power as not necessarily repressive or coercive is in line with that of Hardy and Giddens, who described it as an affective force, a transformative capacity that can influence the course of events (Sheehan et al., 2014). The question is whether talent management allows for the use of power that supports ethical freedom.

The issue that emerges is whether talent management discourses, as they are currently employed, makes the struggle, which underpins ethical freedom, possible, or impossible? The limitations of Foucault's insights for rethinking TM practices pertain to the fact that it remains predominantly a tool of descriptive analysis. So much so, that Foucault's concern with the self-fashioning individual is sometimes described as a mere 'aesthetics of the self' instead of an ethics (Hadot, 2002). How can we use these insights more proactively to move towards talent management practices that support ethical business activities?

\section{The possible: Rethinking talent management}

The challenge seems to lie in how to enable a kind of selfunderstanding that is not mediated and controlled by managerial-inspired discourses already operative within the organisation. Such a controlled discourse would undermine the message that there is space for critical self-reflection that allows for the individual to struggle against organisational pressures. Instead of engaging in an interactive, ongoing process of writing and being rewritten, controlled individuals are essentially following a script that makes discretion impossible. Instead, narration should be embedded in the socio-historical and institutional contexts of people's lives and practices in organisations. What Foucault's methodology afford us is a magnifying glass to scrutinise talent management discourse and practices. We can study the extent to which talent management discursive practices allow the emergence of a subject capable of critical self-reflexivity. Could talent management create meaningful spaces for ethical action? In what follows, we hope to provide a perspective on the relationship between ethics and talent management that moves beyond the micro-dimension, and makes a more systemic contribution.

The first important aspect of rethinking talent management we want to mention is the acceptance of ambiguity and personal struggle. Research in critical management studies suggests that 'identity' is no longer understood in terms of a simplistic sense of self-sameness. Sveningsson and Alvesson (2003: 1164-1165) describe the process through which individuals identify themselves as one of ongoing struggle, so much so that it should be defined as 'identity work', that is, 'the way people are engaged in forming, repairing, maintaining, strengthening or revising the constructions that are productive of a sense of coherence and distinctiveness'. The human subject that they (Sveningsson and Alvesson, 2003: 1184) describe in their research is the location of contradictory discourses, which is stabilised in and through the establishment of narrative self-identity. A kind of 'myth' or life-story is created that allows for continuity and stability amidst flux and ambiguity. Indeed, the notion of identity is inextricably linked to the capacity an individual has to 
keep any particular narrative going. We are 'meaningmaking bundles of relationships and event clusters' (Maclean et al., 2011: 20). As such, our individual agency is fully bound up with specific fields of social practices, and not the accomplishment of an isolated individual, as some talent management practices may assume. Paradoxically, this 'myth' of simplistic self-sameness makes identity struggles both more comfortable and more problematic, since it creates tension and pain alongside the stability it provides, especially when it is at odds with organisational expectations, which often demand a kind of 'hybrid' functioning.

As Clarke et al. (2009: 345) explain, virtue, like identity, can never be a final, stagnant product, precisely because it requires the ongoing employment of the various discursive resources that individuals have access to within organisational life. Talent management interventions must allow for as many as possible discursive resources to be brought into play in order to stimulate debate and offer opportunities for discursively unpacking moral dilemmas. For instance, there is evidence of some employers seeking to engender a more ethical outlook through the use of discourse ethics and ethical decision-making tools (Tansley et al., 2014). Clarke et al. (2009: 332) also studied the way in which individuals draw on contradictory, even antagonistic discursive practices in the process of navigating their own identity. Often these antagonistic discourses, like being both emotionally detached and engaged, both professional and unprofessional, etc., are maintained within the individual's sense of self without destabilising that individual or requiring integration. What however emerges from their account, is that there are few opportunities for employees to actually see and reflect on these paradoxes and critically interrogate the effects this may have on their moral agency. Another important insight is that one of the two sides of the binary discursive structure always seems to maintain its privileged position, namely, emotionally detached is better than emotionally engaged, professional is better than unprofessional, etc. As such, there is no opportunity for the individual to reflect on why and how this happens, or how to resist it.

In practical terms, this would mean to encourage counter-discourses that entail creating the opportunity for employees to explore moments of disjunction or conflict as opportunities for self-reflection. Within talent management, the narration of these should not be portrayed as a failure to meet objectives or behave like 'talent', but instead as opportunities for personal experimentation and exploration. It is in this regard that Barratt's (2008) Foucauldian analysis of the critic, or Hjorth's (2005) analysis of the critic based on his reading of De Certeau as a tactician becomes relevant. It involves the calculation of forces and relationships, the cultivation of alliances, taking defensive measures, furnishing instruments of analysis to support agents who are already in the process of struggle. Such instruments must be able to take account of the embodied, contextual factors that shape institutions over time.

The study undertaken by Ibarra and Barbulescu (2010) shows the applicability of the concept of critical selfnarrative in matters of professional identity. The authors argue that it is possible to show how individuals, in periods of professional transition, create repertoires of narratives, which are constantly updated through their interactions with others. As the work role changes, the narrative repertoire evolves. However, this relation to self is an insufficient condition. For Ibarra and Barbulescu (2010), to promote the successful transition from one work role to another, the narrative must underpin a sense of authenticity, understood as the fidelity to self in time (i.e., the narrator's self), all the while convincing the audience to which it is directed of its validity. If talent management processes offer the opportunity for reflecting on one's relationships with others and with their perspectives, critical self-scrutiny may be more likely (Cunliffe and Coupland, 2011). Talent development initiatives provide for individual and group learning as organisational talent transitions in early career from university to employer then progression up through the career ladder. However, there is a tendency to focus on how talent can meet organisational requirements rather than reflection on social relationships at work (Tansley and Tietze, 2013). To avoid this, the focus of talent management must go beyond the individual, and embrace performance measurement and management strategies that allow for these broader perspectives to be included.

The second aspect that will require attention is for the quantitative measurement to be supplemented with more qualitative approaches to performance, taking the progression of time and the specificities of context into account. Narrative is an important vehicle to study personal growth and changing organisational dynamics over time. By studying patterns of narration within selfappraisals, for instance, we can draw out the way in which individuals' valuation of themselves is bound up with the goals of the organisation and their perception of its contingent power dynamics. We can question whether talent management discursive practices succeed in allowing individuals to reflect on how certain value priorities emerge as salient within their organisations and how these affect their evaluation of themselves. If talent management is all about fostering identities that conform to a dominant, unitarist frame, the conditions of ethical freedom that Foucault views as essential to ethics will be absent. In fact, the emphasis on measurable, quantifiable performance inherent in some talent management approaches makes it unlikely that a more qualitative analysis of value priorities will be undertaken. 
We should ask ourselves: how are the 'hybrid' expectations pertaining to many managerial positions reflected in talent management practices and to what extent are individuals offered opportunities to consider the impact of this hybridity and ambiguity on their sense of self, and their capacity to act as free moral agents? What is required here is reflexive hermeneutics that studies the individual's reading of organisational expectations as they manifest within the talent management system and the individual's own responses to these over time through periodic self-appraisals. For instance, can the individual recall how many times their ethical standpoint was compromised in order to 'make a target' or 'meet a deadline'? Did this bother the individual? For how long? Who did the individual become in the process? Did this person's social interactions, friends, lifestyle change as a result? What one would hope is that the individual, when reflecting on subtle changes over time, would have the opportunity to work on a movie-script of his/her professional life, rather than focusing on 'snapshotpictures' of professional successes.

A practical illustration with purely quantitative performance measures may include studying talent's KPIs (key performance indicators) and unpacking the views of the self that are inscribed therein. One has to consider the ethical implications, for instance, of a team leader's key performance indicators only stipulating that $100 \%$ of his/her staff members should complete their ethics training. Focusing on the measurement of online training in terms of the percentage of completion may assist the organisation in meeting some important compliance requirements, but it serves no purpose in enhancing the moral responsiveness of the team or the leader in charge. Success in these terms casts the team leader (and the training function) in the role of enforcer of the policy, rather than as the champions of ethical reflection and role models in terms of the exercise of moral judgment (Leavitt et al., 2012). Nor does it encourage any self-scrutiny, reflexivity in terms of who the self is becoming over time, and offers no recourse in terms of the specifics of his/her everyday life.

An understanding of the emergence of talent management practices over time and across different contexts allow us to scrutinise its ethical impact and its sustainability implications. Foucault's genealogical analysis reminds us of the importance of considering time and space, but not necessarily in order to control it (Tsoukas and Hatch, 2001). Time is also the horizon within which growth and change should be possible. As such, important shifts in approaches to talent management needs to be scrutinised. The value of time in procuring self-reflection is evident in some of the more positive examples of talent management. Unilever, for instance, makes it clear that 'folding the future in' is a priority for all upcoming talent within the organisation. IBM's
Corporate Service Corps talent development programme is not only spread over 6 months of active learning, but it also encourages an ongoing relationship with stakeholders over time. It also breaks down the barrier between personal and professional life by encouraging participants to share their experience and learning not only with colleagues, but with colleagues and friends. This value of process of integrating one's own development within a broader narrative is central to sustaining practices of self-reflection and sustains ethical freedom, because it encourages individuals not to be trapped in organisational discourses, but to engage with a broader environment.

We should also explore how those being designated as 'talent' shape how institutional dynamics function over time. Are they empowered to shape their organisation's direction within a broader societal context? What IBM and Unilever's practices have in common is the fact that it moves away from individualist navel-gazing toward engendering responsiveness to the contextual challenges faces by others. For example, some of Unilever's key objectives of their talent development for high potential individuals is to 'bring the outside in' and to enhance participants' capacity to engage with people and organisations that they are unlikely to come into contact with otherwise (Gitsham, 2008). The relationality that is part of narration is the condition for social being, social consciousness and social action, which forms the basis of structures, institutions and society as such (Sommers, 1994).

We also need to consider how the 'talent' designation, and the practices that accompany it, mediate the self's relationships with others and the power dynamics within organisations. Allowing talent's 'petites narratives', namely, small, particular stories of self-discovery to play an important part in further talent management processes is crucial in maintaining the ethical dimension of organisations. According to Leavitt et al. (2012), positive role models can provide ethical guidance and operate as a moral referent other for individuals to relate to. They assert that the particularistic obligations that individuals feel towards such a person act as moral obligations and are stronger than universal moral obligations that might prevail within an organisation and thus may overcome any ethical tensions inherent in the dominant organisational narratives. In his book, Kristensson-Ugla (2010: 16) also explains: 'understanding of the person as homo capax, the reader should not be considered as either almighty or powerless, but rather as a human being capable of action as well as suffering, production as well as reception, writing as well as reading'. The subject, as Barratt's (2008) analysis of Foucault indicated, becomes capable of a tactical response is possible which create new spaces for change through an assessment of current conditions and constraints. 
This will also mean that individuals must periodically have the opportunity to reflect on their performance over a longer term, even if the individual changed jobs or moved to another company in the meantime. It would also mean that the organisation must create opportunities for discussion of what it is becoming in and through its practices. Strategic planning sessions may present the ideal occasions for such reflection. The question at these junctures should not just be, 'How should we change our talent management practices to meet our new strategic objectives?' but rather 'How did years and years of talent management practices make these new strategic objectives seem appropriate?' The basic question here is: 'Do we like who and what we are becoming as individuals, and as an institution in and through our practices?'

\section{Conclusion}

Our analysis of talent management revealed the risks that lie latent in talent management discourse and practice, but also signals the opportunities that organisations may embrace. Talent management discourses have the power to support or undermine ethical subjectivity and thereby sustain the kind of identity construction that can undermine the ethical subjectivity of organisational talent. Treating talent merely as 'scarce resources' needed to procure profit indicates the instrumentality that characterises relations between organisations and people, and violates the basic ethical standards of respect, dignity and equality. Analysing the dominant organisational narratives underpinning talent management practices allowed us to see how it can have a negative impact on identity construction over time, and may make it extremely challenging to create opportunities for selfreflection and ethical judgment. Furthermore, talent management practices that suffers from the preoccupation with individual rather than social and political identity, and with identity control, will most likely undermine ethics in organisations.

We point out, however, that some organisations use their talent management initiatives to procure exactly the opposite, namely, self-critical individuals with a social conscience and contextual sensitivity. These kinds of talent management practices are more likely to afford talent the opportunity to reflect upon the ongoing struggles between individuals and institutions that shape personal and institutional identity. More importantly, they allow individuals to view themselves in relation to others and to the world, rather than as scarce individual instruments, and they support the ongoing ethical struggle with oneself, others, and institutions. This may allow talent to develop as critical tacticians (Barratt, 2008), and as such, sustain ethical reflection in all dimensions of the organisation.
In conclusion, the challenge that we wish to pose to talent management practitioners is to engage in ongoing critical reflection on how organisational practices evolve over time. If we pay close enough attention, we will see that constructs such as 'talent' both reveal and perpetuate value commitments and assumptions that we may have forgotten we have, or that simply escape recognition. Engaging in a closer interrogation of our practices offers us the opportunity to rediscover and rewrite ourselves and our institutions, and to reconsider who we are becoming. This capacity to self-reflectively analyse the past, engage actively in struggles to protect ethical values in the present, and embrace the possibilities to build a sustainable world that lie latent in the future, is what could give talent management its ethical force.

\section{References}

Alvesson, M. and D. Kärreman, 2007, "Unraveling HRM: Identity, ceremony, and control in a management consulting firm”. Organisation Science, 18: 711-723.

Alvesson, M. and D. Kärreman, 2011, "Decolonizing discourse: Critical reflections on organizational discourse analysis". Human Relations, 4: 1121-1146.

Alvesson, M. and H. Willmott, 2002, "Identity regulation as organisational control: Producing the appropriate individual". Journal of Management Studies, 39: 619-644.

Banks, M., D. Vera, S. Pathak and K. Ballard, 2016, "Stakeholder management as a source of competitive advantage: A relationship and portfolio perspective". Organizational Dynamics, 45: 18-27.

Barratt, E., 2008, "The later Foucault in organisation and management studies". Human Relations, 61: 515-537.

Beenen, G. and J. Pinto, 2009, "Resisting organisational-level corruption: An interview with Sherron Watkins". Academy of Management Learning \& Education, 8: 275-289.

Björkman, I., M. Ehrnrooth, K. Mäkelä, A. Smale and J. Sumerlius, 2013, "Talent or not? Employee reactions to talent identification". Human Resource Management, 52: 195-214.

Burr, V., 2003. Social construction, 2nd ed. New York: Routledge.

Calvard, T. and K. Sang, 2017, "Complimenting psychological approaches to employee well-being with a socio-structural perspective on violence in the workplace: an. alternative research agenda". The International Journal of Human Resource. Management, 28: 2256-2274.

Clarke, C., A. Brown and V. Hope-Hailey, 2009, "Working identities? Antagonistic discursive resources and managerial identity". Human Relations, 62: 323-352.

Collings, D., 2014, "Toward mature talent management: Beyond shareholder value". Human Resource Development Quarterly, 25: 301-319.

Costas, J. and P. Fleming, 2009, "Beyond dis-identification: A discursive approach to self-alienation in contemporary organisations". Human Relations, 62: 353-378.

Courpasson, D., 2017, "The politics of everyday". Organisation Studies, 38: 843-859. 
Crane, A., D. Knights and K. Starkey, 2008, "The conditions of our freedom: Foucault, organisation, and ethics". Business Ethics Quarterly, 18: 299-320.

Cunliffe, A. and C. Coupland, 2011, "From hero to villain to hero: Making experience sensible through embodied narrative sensemaking". Human Relations, 65: 63-88.

De Certeau, M., 1990. L'invensiton du quotidien I, Arts de Faire. Folio Essais n ${ }^{\circ} 146$. Paris: Gallimard.

Deslandes, G., 2012a, "The care-of-self ethic with continual reference to socrates: Towards ethical selfmanagement". Business Ethics: A European Review, 21: 325-338.

Deslandes, G., 2012b, "Power, profits, and practical wisdom: Ricoeur's perspectives on the possibility of an ethics in institutions". Business and Professional Ethics Journal, 31: $1-24$.

Dey, P. and S. Teasdale, 2016, "The tactical mimicry of social enterprise strategies: Acting 'as if' in the everyday life of third sector organisations". Organisation, 23: 485-504.

Downs, Y. and S. Swailes, 2013, "A capability approach to organizational talent management". Human Resource Development International, 16: 267-281.

Dries, N., 2013, "The psychology of talent management: A review and research agenda". Human Resource Management Review, 23: 272-285.

Dutton, J., L. Roberts and J. Bednar, 2010, "Pathways for positive identity construction at work: Four types of positive identity and the building of social resources". Academy of Management Review, 35: 265-293.

Foucault, M., 1994. Ethics. subjectivity and truth. The essential works 1. Trans. P. Rabinov. New York: New Press.

Foucault, M., 2005. "The hermeneutics of the subject". In Lectures at the College de France, 1981-1982. Macmillan: Palgrave.

Fusaro, P. and R. Miller, 2003. What went wrong at Enron; Everyone's guide the largest bankruptcy in US history. New York: John Wiley and Sons.

Gallardo-Gallardo, E., N. Dries and T. González-Cruz, 2013, "What is the meaning of 'talent' in the world of work?" Human Resource Management Review, 23: 290-300.

Gelens, J., N. Dries and J. Hofmans, 2013, "The role of perceived organisational justice in shaping the outcomes of talent management: A research agenda". Human Resource Management Review, 23: 341-353.

Gitsham, M., 2008. Developing the global leader of tomorrow. Berkhamsted, Hertfordshire, UK: Ashridge.

Glee, C. and A. Roger, 2004. Bilan de compétence et projet professionnel: Les limites des normes nationales et organisationnelles en matière d'orientation professionnelle. Institut International de l'audit Social, Proceedings from the 6th conference Tunis: Université du Printemps.

Greenwood, M., 2002, "Ethics and HRM: A review and conceptual analysis". Journal of Business Ethics, 36: 261-278.

Grey, C., 1994, "Career as a project of the self and labour process discipline". Sociology, 28: 479-497.

Hadot, P., 2002. Exercices spirituels et philosophie antique. Paris: Albin Michel.

Hjorth, D., 2005, "Organisational entrepreneurship: With de Certeau on creating heterotopias (or spaces for play)". Journal of Management Inquiry, 14: 386-398.
Holden, N. and V. Vaiman, 2013, "Talent management in Russia: Not so much war for talent as wariness of talent". Critical Perspectives on International Business, 9: 129-146.

Hoyer, P. and C. Steyart, 2015, "Narrative identity construction in times of career change: Taking note of unconscious desires". Human Relations, 68: 1837-1863.

Ibarra, H. and R. Barbulescu, 2010, "Identity as narrative: prevalence, effectiveness, and consequences of narrative identity work in macro work role transitions". Academy of Management Review, 35: 135-154.

Ibarra-Colado, E., S. Clegg, C. Rhodes and M. Kornberger, 2006, "The ethics of managerial subjectivity". Journal of Business Ethics, 64: 5-55.

Iles, P., 2013, "Commentary on the meaning of 'talent' in the world of work". Human Resource Management Review, 23: 301-304.

Jack, G., M. Greenwood and J. Schepper, 2012. "Frontiers, intersections and engagements of ethics and HRM". Journal of Business Ethics, 111: 1-12.

Jardat, R., 2015, "New emerging concepts and ideas for management". European Management Review, 12: 1.

Jones, C., 2002, "Foucault's inheritance/inheriting Foucault". Culture and Organisation, 8: 225-238.

Kantor, J. and D. Streitfeld, 2015. "Ideas in a bruising workplace". 15 August, New York Times. Available from https://www.nytimes.com/2015/08/16/technology/insideamazon-wrestling-big-ideas-in-a-bruising-workplace.html (accessed January 19, 2018).

Kim, Y., R. Williams, W. Rothwell and P. Penaloza, 2014, “A strategic model for technical talent management: A model based on a qualitative case study". Performance Improvement Quarterly, 26: 3-121.

Krishnan, T. N. and H. Scullion, 2017, "Talent management and dynamic view of talent in small and medium enterprises". Human Resource Management Review, 27: 431-441.

Kristensson-Ugla, B., 2010. Ricoeur, hermeneutics and globalization. London: Continuum.

Kunda, G., 1992. Engineering culture: Control and commitment in a high-tech corporation. Philadelphia, PA: Temple University Press.

Leavitt, K., S. Reynolds, C. Barnes, P. Schilpzand and S. Hannah, 2012, "Different hats, different obligations: Plural occupational identities and situated moral judgments". Academy of Management Journal, 55: 1316-1333.

Maclean, M., C. Harvey and R. Chia, 2011, "Sensemaking, storytelling and the legitimization of elite business careers". Human Relations, 65: 17-40.

Mboukou, S., 2015, "Entre stratégie et tactique". Le Portique, 35 : 1-16.

Meyers, M. and M. van Woerkom, 2014, "The influence of underlying philosophies on talent management: Theory, implications for practice, and research agenda". Journal of World Business, 49: 192-203.

Michaels, E., H. Handfield-Jones and E. Axelrod, 2001. The war for talent. Boston, MA: Harvard Business School Press.

Painter-Morland, M. and R. Ten Bos, 2011. Business ethics and continental philosophy. Cambridge: Cambridge University Press.

Randal, J. and I. Munro, 2010, "Foucault's care of the self: A case from mental health work". Organisation Studies, 39: 1485-1504. 
Sewell, G., J. Barker and D. Nyberg, 2011, "Working under intensive surveillance: When does 'measuring everything that moves' become intolerable?" Human Relations, 65: 189-215.

Sheehan, C., H. De Cieri, B. Cooper and R. Brooks, 2014, "Exploring the power dimensions of the human resource function". Human Resource Management Journal, 24: 193-210.

Silzer, R. and B. Dowel (Eds), 2010. Strategy-driven talent management: A leadership imperative. San Francisco, CA: John Wiley \& Sons.

Sommers, M., 1994, "The narrative constitution of identity: A relational and network approach". Time and Society, 23: 605-649.

Spector, B., 2003, "HRM at Enron: The un-indicted coconspirator". Organisational Dynamics, 32: 207-220.

Stahl, G., I. Björkman, E. Farndale, S. Morris, J. Paauwe, P. Stiles, J. Trevor and P. Wright, 2012, "Six principles of effective global talent management". MIT Sloan Management Review, 53: 1-34.

Sturdy, A., 1998, "Customer care in a consumer society: Smiling and sometimes meaning it?" Organisation, 5: 27-53.

Sveningsson, S. and M. Alvesson, 2003, "Managing managerial identities: Organisational fragmentation, discourse and identity struggle". Human Relations, 56: 1163-1193.

Swailes, S., 2013, "The ethics of talent management". Business Ethics: A European Review, 22: 332-346.

Swailes, S., 2016, "The cultural evolution of talent management: A memetic analysis". Human Resource Development Review, 15: 340-358.

Swailes, S., Y. Downs and K. Orr, 2014, "Conceptualising inclusive talent management: potential, possibilities and practicalities". Human Resource Development International, 17: 529-544.

Tansley, C., 2011, "What do we mean by the term 'talent' in talent management?' Industrial and Commercial Training, 43: 266-274.

Tansley, C. and S. Tietze, 2013, "Rites of passage through talent management progression stages: An identity work perspective". International Journal of Human Resource Management, 24: 1799-1815.
Tansley, C., S. Kirk and C. Fisher, 2014, "Navigating the ethical maze through design action research". European Journal of Training and Development, 38: 456-482.

Thornborrow, T. and A. Brown, 2009, "Being regimented: Aspiration, discipline and identity work in the British parachute regiment". Organisation Studies, 30: 255-376.

Thunnissen, M., P. Boselie and B. Fruytier, 2013, "Talent management and the relevance of context: Towards a pluralistic approach". Human Resource Management Review, 23: 326-366.

Townley, B., 1993, "Foucault, power/knowledge, and its relevance for human resource management". Academy of Management Review, 18: 518-545.

Townley, B., 2002, "Managing with modernity". Organisation, 9: 549-573.

Townley, B., 2008. Reason's neglect. Rationality and organizing. Oxford: Oxford University Press.

Tsoukas, H. and M. J. Hatch, 2001, "Complex thinking, complex practice: The case for a narrative approach to organisational complexity". Human Relations, 54: 979-1013.

Tymon, W., S. Stumpf and J. Doh, 2010, "Explaining talent management in India: The neglected role of intrinsic rewards". Journal of World Business, 45: 109-121.

Van den Brink, M., B. Fruytier and M. Thunnissen, 2013, "Talent management in academia: Performance systems and HRM policies". Human Resource Management Journal, 23: 180-195.

Van Dijk, T., 2014. Discourse and knowledge: A sociocognitive approach. Cambridge: Cambridge University Press.

Watson, T., 1995, "Rhetoric, discourse and argument in organisational sense making: A reflexive tale". Organisational Studies, 16: 805-821.

Whittle, A., 2005, "Preaching and practising flexibility: Implications for theories of subjectivity at work". Human Relations, 58: 1301-1322. 